\title{
RELATIONSHIP OF INCREASE IN BODY WEIGHT, FATTENED LIVER WEIGHT AND LIVER QUALITY IN GEESE OF DIFFERENT BREEDS, DETERMINED ON THE BASIS OF FORCE FEEDING METHODS
}

\author{
J. SZIGETI ${ }^{a}, Z S$. TURCSÁN ${ }^{b}$, E. BIRKÁs ${ }^{b}$, F. BONYHÁDI $^{b}$, and A. VARGA ${ }^{\mathrm{b}}$ \\ ${ }^{a}$ Institute of Food Science, Faculty of Agricultural Sciences, Pannon University of Agricultural Sciences, \\ H-9200 Mosonmagyaróvár, Lucsony u. 15-17. Hungary \\ b MERIÁN, Orosháza Co. H-5901 Orosháza, Október 6. u. 8. Hungary
}

(Received: 5 November 1998; accepted: 8 March 1999)

\begin{abstract}
From the age of 9 weeks, 90-90 Kolos, Gourmaud and Babati goose breeds were force fed with 2 different types of technology and 3 types of feedstuff. Force feeding technologies were the traditional Hungarian and Israeli soft groats quick methods. In the case of the latter, feedstuff was fed both in a pre-fermented (Lactobacillus plantarum lactic acid bacteria) form and without fermentation. Frequency of daily force feeding was gradually increased from 2 to 6 until the 21st day of force feeding. Live weight before and after fattening and liver weight were measured in the case of each breed and treatment. Liver quality was also determined. On the basis of our results, differences in liver weight average were significantly influenced only by the genetic property of the breed. Liver quality was also influenced by the method of force feeding of one breed (Babati). Feedstuff tested did not result in significant differences in liver weight or in liver quality. Independently of the breed very close correlation was found between "fattening weight" and liver weight $(r=0.98)$ and between "fattening weight" and liver quality grade $(r=-0.97)$.
\end{abstract}

Keywords: goose fatty liver weight, body weight, liver quality grade, force-feeding

Many publications aimed to find correlation between parameters that might influence the fattened liver weight of ducks and geese. It was found by BABILE and coworkers (1987) that after force feeding of 3 groups of Muscovy ducks there was a significant relation between liver weight (LW) and total feed (DM) intake. Experimental results suggest connection between $\mathrm{LW}$ and increase in body weight (BW) during force feeding, independently of sex and breed of ducks. In another paper, BABILE and coworkers (1988) established that the type of diet did not, while genotype differences of ducks did affect LW significantly. However, CHEN and co-workers (1985) found a significant difference of about $30 \mathrm{~g}$ between $\mathrm{LW}$ of geese fed with diet of cooked or 
uncooked maize plus $0.8 \% \mathrm{NaCl}$. LW was slightly, yet significantly heavier in geese given alfalfa meal as major dietary fibre sources than those given barley bran (CHEN et al., 1993).

MAMAEV (1986) measured LW of above $400 \mathrm{~g}$ in geese that weighed $4.2 \mathrm{~kg}$ to $4.3 \mathrm{~kg}$ at the start of fattening. These geese have gained $78-85 \%$ of their initial body weight during the 3 weeks of feeding. SHALEV and co-workers (1986) revealed by regression analysis that $\mathrm{LW}$ increased by $69 \mathrm{~g}$ for $1 \mathrm{~kg}$ of increase in $\mathrm{BW}$ after fattening and that it increased by $100 \mathrm{~g}$ for a $1 \mathrm{~kg}$ increase in BW before fattening.

POUJARDIEU and co-workers (1994) found that, in Italian and Polish goslings, there was no relationship between LW and liver quality grade (LQG). Studies by BóDI (1992) showed significant correlation between 14 weeks' BW and carcass weight of males and females of Hungarian geese.

Several authors, including JOUGLAR and co-workers (1992), found relationship between LW and carcass and body weight. Carcass weight increased from $3.183 \mathrm{~g}$ to $5.611 \mathrm{~g}$ after 34 force-feeding sessions, while liver weight increased tenfold in 9 groups of 20 caged Mulard ducks. It means that the increase in carcass weight was caused about $20 \%$ by liver weight. After a short force period of 12 days AUVERGNE and co-workers (1995) noticed that $37 \%$ of the total weight gain resulted from increase in LW. After force feeding of 13 days, ROUVIER and co-workers (1994) measured BW, paletot weight and LW in some duck breeds and found a good correlation between BW and LW. Besides examining the effect of genotype on LW in geese PENKOVA and BóDI (1995) found correlation between LW and BW except for the breed of Hungarian white breeds.

Two different breeds of Hungarian white and a crossbreed were force-fed on a diet of maize, fresh meal-and-bone, sunflower oil meal and vegetable oil by VEREMEENKO and KUTNYUK (1995) and among others body weight, body fat and liver weight were measured before and after finishing. Calculated data are given with respect to liver weight and growth weight. Correlation of about $r=0.55$ was found between LW and BW after finishing. It can be figured out from these results that the foie gras weight gain (LW) exceeded $12 \%$ of live weight gain after finishing of both breeds.

This paper reports the results of investigations carried out to determine the goose breed which produces the heaviest foie gras with the best quality and whether there is a correlation between finished live weight BW and LW independently of the force-fed technology and breed of goose. 


\section{Materials and methods}

\subsection{Goose breeds examined}

It was a common property of the geese tested that they were bred from Toulouse goose for different selection purposes. All three liver hybrids tested belonged to the Landes group of breed.

1.1.1. Kolos liver hybrid. It was bred in Denmark by phenotype selection of Landes goose. The purpose of its breeding was large body growth and extremely large liver growth. Selection has proved to be successful, this hybrid can grow large liver of $800 \mathrm{~g}$ to $1000 \mathrm{~g}$. However, one direction selection had a negative influence on prolification. An average goose has approximately 20-22 offsprings.

1.1.2. Gourmaud liver hybrid. This is a Landes genotype liver hybrid goose bred for liver production. This liver hybrid has good liver growth ability (600 g to $800 \mathrm{~g}$ ) and prolification is also satisfactory (30-35 offsprings per goose).

1.1.3. Babati liver hybrid. This hybrid is a crossbred of Hungarian white gander and Landes geese. Its liver production is $600 \mathrm{~g}$ to $700 \mathrm{~g}$ /goose, prolification is 28-30 offsprings per goose.

Flocks consisting of 500-500 geese belonging to the same breed were formed and then 90-90 groups with a gander ratio of 50\% were randomly selected and further divided into 3 sets, according to fattening type.

\subsection{Fattening method}

According to "traditional" technology known in Hungary, geese were fed for 21-23 days with cooked maize of $13.5 \mathrm{~kg}$ to $14.0 \mathrm{~kg}$, soy groats of $0.5 \mathrm{~kg}$ containing $42 \%$ crude protein, feedstuff pea of $0.3 \mathrm{~kg}$ with $28 \%$ crude protein, $1.0-2.0 \% \mathrm{NaCl}$ calculated feedstuff weight, goose fat of $1 \%$ to $1.5 \%$ and zeolite of $0.3 \%$ to $0.4 \%$ per bird.

Another fattening technology applied was the Israeli soft-groat technology, where $15-17 \mathrm{~kg}$ wet ground maize, $0.8 \mathrm{~kg}$ soy groats containing $42 \%$ crude protein content, $0.3-1.0 \% \mathrm{NaCl}, 0.2-0.7 \%$ goose fat and $1 \%$ granulated bentonite as binding agent were used for each bird.

In the case of the third fattening method, Israeli soft groats were pre-fermented at a temperature of $20^{\circ} \mathrm{C}$ for $24 \mathrm{~h}$ with Lactobacillus plantarum (NCAIM B1415) homofermentative lactic acid bacteria. Rate of inoculation of liquid culture was adjusted in such a way, that $\mathrm{pH}$ of feedstuff would reach 4.5-5.0 value a day later. Birds were fed with feedstuff mixture 2 and 3 with Israeli quick force feeding equipment. Force-feeding was performed by the same tender in the case of all of three goose breeds. 
The fattening time was 21 days in all three fattening methods. Number of force feedings was defined as 2 in the first 3 days then 3 in the following 4 days etc.

\subsection{Evaluation of results}

Cutting and disassembling were made separately. A staff of 5 experts did weight measurements (body and liver weight) and liver classification. Quality classification system of goose livers is illustrated in Table 1. Although these principles of liver classification are not fixed in standards they are generally accepted in the Hungarian poultry industry. Evaluation of results was figured out by two factor (breed and fattening method) variance analysis and linear regression analysis (increase in weight during force feeding - liver weight and liver quality grade).

If blood was found in vessels or tissue of liver, classification was altered according to the following way: blood in arteria hepatica, vena portae or vena hepatica, value of quality decrease is 0.2 ; blood in liver capillaries or interstitial blood decreases class with $0.1-0.5$ value.

Table 1

Directives of liver classification

\begin{tabular}{|c|c|c|c|c|}
\hline & & First class (1.0) & Second class (2.0) & Third class (3.0) \\
\hline 1 & Liver weight & $500 \mathrm{~g}$ to $850 \mathrm{~g}$ & $450 \mathrm{~g}$ to $850 \mathrm{~g}$ & $400 \mathrm{~g}$ \\
\hline 2 & Substance of liver & $\begin{array}{l}\text { - well-matured lobes } \\
\text { - putty-like to touch } \\
\text { - elastic substance } \\
\text {-slightly soft }\end{array}$ & $\begin{array}{l}\text { - less putty-like to } \\
\text { touch } \\
\text { - one-third part of } \\
\text { lobule is fleshy to } \\
\text { touch }\end{array}$ & $\begin{array}{l}\text { - both loose or } \\
\text { contact substance } \\
\text { allowed }\end{array}$ \\
\hline 3 & Colour of liver & $\begin{array}{l}\text { - uniformly light } \\
\text { - occasional } \\
\text { haemorrhage } \\
\text { disappears in ice }\end{array}$ & $\begin{array}{l}\text { - discoloration on the } \\
\text { one-tenth part of } \\
\text { liver allowed } \\
\text { (in spots) }\end{array}$ & $\begin{array}{l}\text { - deeper } \\
\text { discoloration on the } \\
\text { one-fourth part of } \\
\text { liver surface allowed }\end{array}$ \\
\hline 4 & Intact character of liver & $\begin{array}{c}\text { - intact liver, smooth } \\
\text { surface } \\
\text { - intact Glysson } \\
\text { membrane }\end{array}$ & $\begin{array}{c}- \text { surfacial injuries } \\
1-5 \mathrm{~mm} \text { deep }\end{array}$ & $\begin{array}{c}\text { - injured, deep } \\
\text { haemorrhagic } \\
\text { regions }\end{array}$ \\
\hline
\end{tabular}




\section{Results and discussion}

2.1. Liver weight and liver quality grade as a function of various goose breeds and methods of force feeding

Liver weight averages in the case of the three hybrids and the three force feeding technologies are shown in Table 2 and Fig. 1.

LSD 95\% value depending on breed or force feeding methods was $34.7 \mathrm{~g}$ in liver weight whereas that depending on breed and force feeding method proved to be $65.4 \mathrm{~g}$. On the basis of these findings, the following conclusions can be drawn.

- Liver production of Kolos is better than that of Gourmaud, while Gourmaud geese liver production reached greater value than that of Babati.

- The examined force feeding methods did not indicate significant difference in liver weight.

Liver quality grade in the case of various hybrids and experimental force feeding methods are shown in Table 3.

Table 2

Liver weight of different liver hybrid geese, using various force feeding methods

\begin{tabular}{|c|c|c|c|}
\hline \multirow{3}{*}{ Force feeding method } & \multicolumn{3}{|c|}{ Liver weight average $(\mathrm{g})$ and standard deviation $(\mathrm{n}=30)$} \\
\hline & \multicolumn{3}{|c|}{ Breed } \\
\hline & Kolos & Gourmaud & Babati \\
\hline Traditional & $667.5 \pm 74.2 *$ & $590.4 \pm 133.3$ & $482.5 \pm 115.9$ \\
\hline Israeli & $662.1 \pm 70.2$ & $597.9 \pm 139.7$ & $484.3 \pm 111.1$ \\
\hline Israeli (with pre-fermented feedstuff) & $665.4 \pm 120.5$ & $543.9 \pm 125.3$ & $500.4 \pm 101.9$ \\
\hline
\end{tabular}

* LSD 95\% between lines or columns is $34.7 \mathrm{~g}$ and between treatments is $65.4 \mathrm{~g}$

Table 3

Liver quality grade in the case of various hybrids and force feeding methods

\begin{tabular}{lccc}
\hline \multirow{2}{*}{ Force feeding method } & \multicolumn{3}{c}{ Liver quality grade and standard deviation $(\mathrm{n}=30)$} \\
& \multicolumn{3}{c}{ Breed } \\
\cline { 2 - 4 } & Kolos & Gourmaud & Babati \\
\hline Traditional & $1.11 \pm 0.31^{*}$ & $1.53 \pm 0.88$ & $2.07 \pm 1.38$ \\
Israeli & $1.07 \pm 0.26$ & $1.32 \pm 0.67$ & $1.61 \pm 0.83$ \\
Israeli-modified & $1.18 \pm 0.47$ & $1.61 \pm 0.91$ & $1.93 \pm 1.12$ \\
\hline
\end{tabular}

* LSD $95 \%$ between lines or columns is 0.26 and between treatments is 0.45 

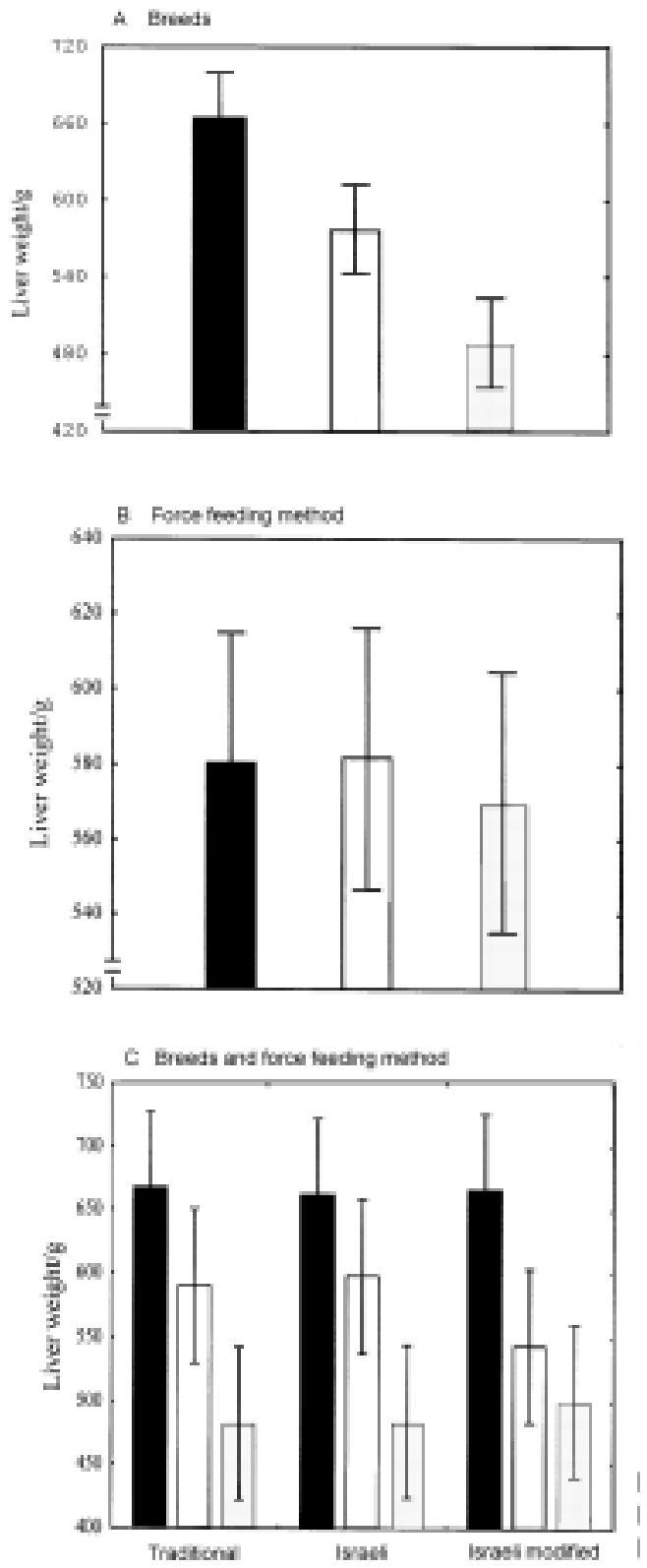

Fig. 1. Liver weight average of different geese hybrids and of various force feeding methods. A,C: $\square$ Kolos, $\square$ Gourmaud, $\square$ Babati; B: $\square$ Traditional, $\square$ Israeli, $\square$ Israeli modified 
As for liver quality grades, LSD 95\% value depending on breed or force feeding method is 0.26 whereas that depending on breed and force feeding method is 0.45 . Evaluating these results we can conclude that:

- Liver quality - where bleeding, colour, etc. are also important besides weight further emphasises superiority of Kolos and Gourmaud over Babati, which is also reflected in the results of liver weight measurements.

- Israeli force feeding method might be successful without pre-fermentation of feedstuff and it results in better liver quality in the case of breeds having originally poor liver quality (Fig. 2).

2.2. Relationship of increase in body weight during fattening with liver weight and liver quality grade

The terms "increase in body weight" or "fattening weight" mean the difference in live weight between starting force fed and before slaughtering.

Investigations have shown that increase in body weight does not depend on the method of force-feeding and it slightly rests with breed. The larger the "fattening weight" is, the larger the liver weight will be (Fig. 3).

A similar relationship was found between fattening weight and liver quality. Independently of breed, a larger fattening weight resulted in better quality (Fig. 4).

Our investigations have revealed that liver production is better in the case of hybrids showing a larger increase in weight during fattening. Moreover, within a given population, the liver weight of geese, which have a larger increase in weight, is also larger. We have to emphasise that confidence interval of the regression line showing fattening weight dependent change of liver quality classification and liver weight is occasionally greater under industrial circumstances. Considering that experiments like ours could not be found in the literature, comparison of our results with those of other authors was not possible. 

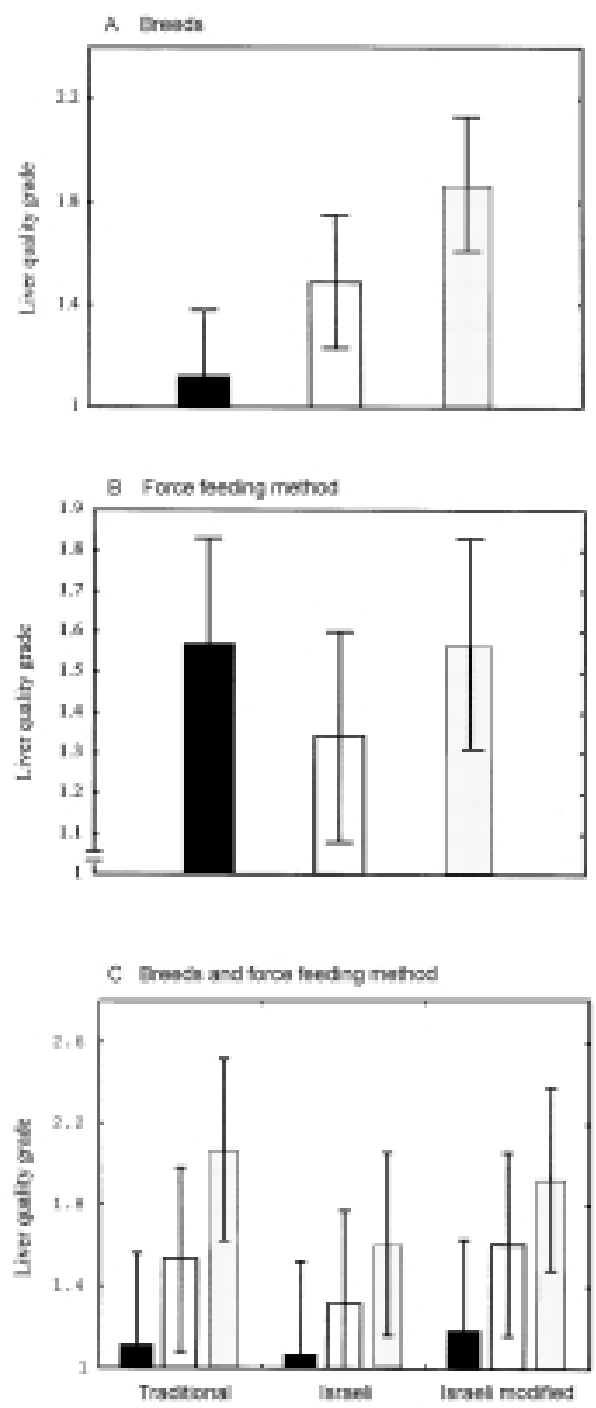

Fig. 2. Liver quality grade on the effect of different geese hybrids and of force feeding methods. A,C: $\square$ Kolos, $\square$ Gourmaud, $\square$ Babati; B: $\square$ Traditional, $\square$ Israeli, $\square$ Israeli modified 


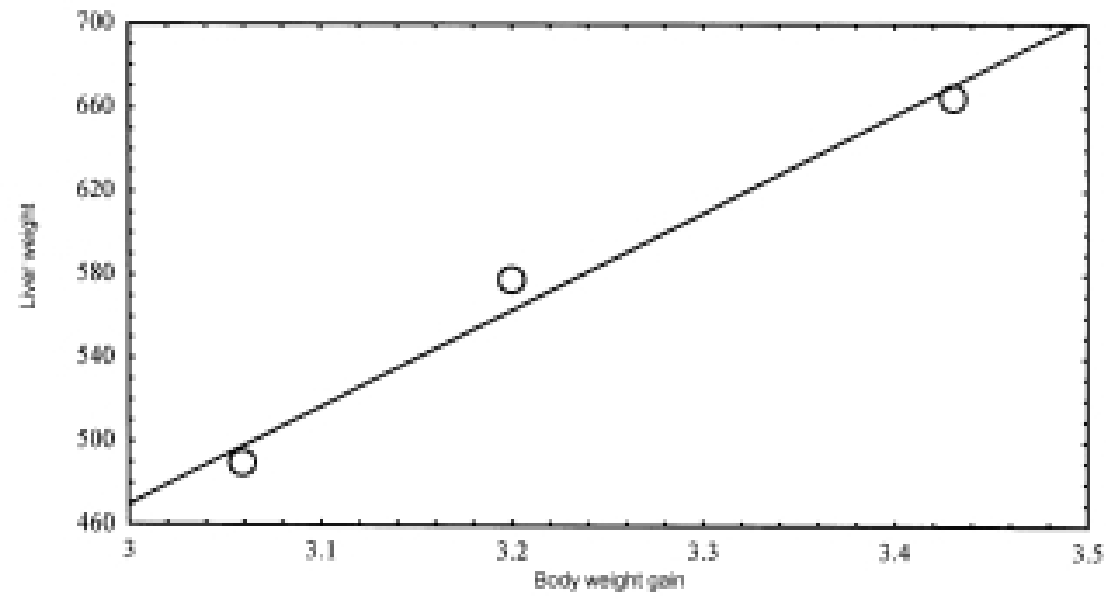

Fig. 3. Correlation between liver weight and body weight gain during force feeding (LSD 95\% around straight is $\pm 22 \mathrm{~g}$ ), $\mathrm{r}=0.98$

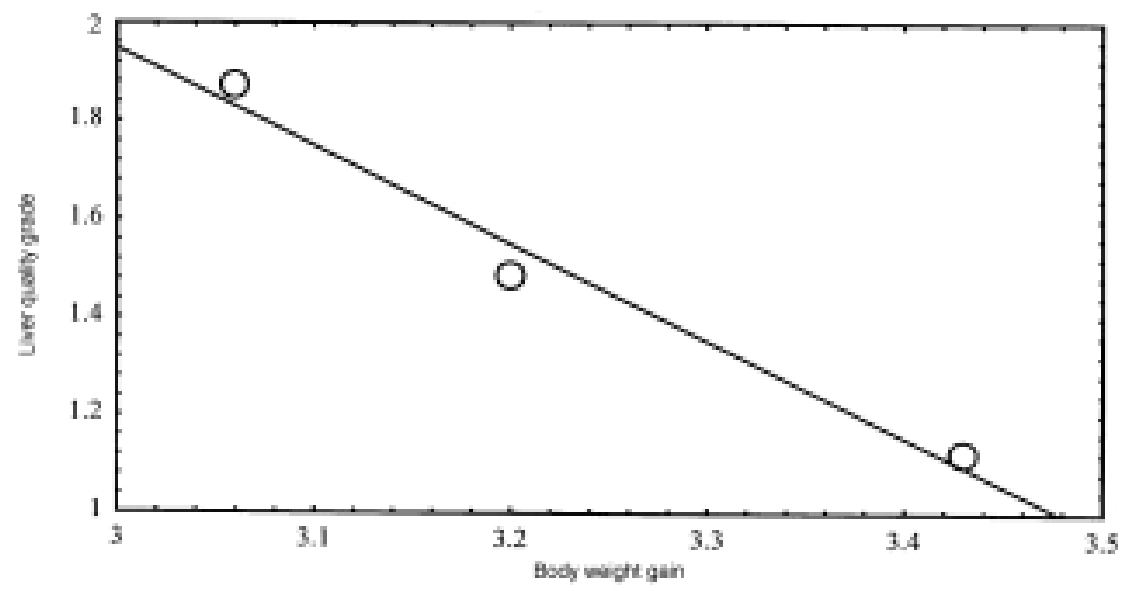

Fig. 4. Relation between liver quality grade and body weight gain during force feeding (LSD 95\% around regression line is \pm 0.11$), r=-0.97$ 
The authors wish to thank the Hungarian Committee of Technical Development (OMFB) for financing this work

\section{References}

AuVErgne, A., REMIGNON, H., BABILE, R. \& BAUDONNET-LENFANT, C. (1995): Evolution corporelle au cours du gavage chez le canard de Barbarie. Arch. Geflügelkunde, 59, 234-240.

BABILE, R., Auvergne, A., DelPeCh, P. \& Meirieu, O. (1987): Evolution de la consommation de mais au du gavage et incidence sur la production de foie gras chez le canard de Barbarie. Ann. Zootechn., 36, 73-83.

BABILE, R., AUVERGNE, A. \& DelPeCH, P. (1988): Influence d'un rationnement precoce sur les performences de gavage de differents types genetiques de canards (males Barbarie et mulards). Colloques de l'INRA, 42, 111-123.

BÓDI, L. (1992): Magyar és landesi fajta májtermelőképességének vizsgálata egyszer tépett ludakon. (A study of liver-producing ability in Hungarian and Landes geese after plucking.) Állattenyésztés és Takarmányozás, 41, 123-131.

CHEN, L., HV, J. P. \& CHEN, S. Y. (1985): Some technical factors in the production of fat liver in geese. Chin. J. Anim. Sci. Zhongguo Xumu Zazhi., 6, 16-19.

CHEN, Y. H., HSV, J. C, YU, B. \& CHEN, T. F. (1993): Effects of alfalfa meal and barley bran as major dietary fiber sources on growth performance, intestine fermentation and cellulase activity of goslings. J. Chin. Soc. Anim. Sci., 22, 1-10.

Jouglar, J. Y., ANTOINE, J., BenARD, G., KOlCHACK, S. \& LABIE, C. (1992): Aufstellung einiger Wachstumparameter für das Stopfen von Mulard-Enten. Bayerisch. Landwirtsch. Jahrbuch, Sonderheft 69, 125-132.

MAMAEV, V. V. (1986): Novye priemy kormleniya ivyrashchivaniya v promyshlennom zhivotnovodstve. (New method for feeding of farm animals.) 16-23 Zagorsk, USSR. -ref.: Accelerated fattening of geese for foie gras. Referativny Zhurnal (1978), 8 (58), 666.

PENKOVA, T. V. \& BÓDI, L. (1995) A genotípus hatása a ludak májtömegére. (The effect of genotype on liver weight in geese.) Állattenyésztés és Takarmányozás, 44, 403-409.

POujARDieu, B., Rouvier, R., RousSelot-PAilley, D., GuY, G., ROSINSKI, A. \& WeZYK, S. (1994): Croissance et aptitude au gavage d'oies de 3 genotypes. Ann. Zootechn., 43, 197-211.

Rouvier, R., GuY, G., RousSElOT-PAILlEy, D. \& POUJARDIEU, B. (1994): Genetic parameters from factorial crossbreeding in two duck strains (Anas platyrhynchos) Brown Tsaiya and Pekin, for growth and fatty liver traits. Brit. Poultry Sci., 35, 509-517.

SHALEV, B., PASTERNAK, H. \& KATZ, Z. (1986): The relationship between body and fattened liver weights in geese of different breeds and sexes. 7th Eur. Poultry Conf., Paris 1, 85-89.

VEREMEENKO, R. P. \& KUTNYUK, P. I. (1995): Prediction of the results of fattening geese for fatty liver. Nauchno Tekhnichieskii Byullete, Ukrainskii Nauchno Issledovatelskii Institut Ptitsevodstva, 34, $30-32$. 